\title{
Different locations of cholesteryl ester transfer protein and phospholipid transfer protein activities in plasma
}

\author{
H. Speijer, J.E.M. Groener *, E. van Ramshorst and A. van Tol \\ Department of Biochemistry, Faculty of Medicine and Health Sciences, Erasmus University Rotterdam, Rotterdam (The Netherlands)
}

(Received 20 March, 1991)

(Revised, received 1 July, 1991)

(Accepted 8 July, 1991)

\section{Summary}

Activities of cholesteryl ester transfer protein (CETP) and phospholipid transfer protein (PLTP) were measured in plasma of four vertebrate species: man, rabbit, pig, and rat. The activities were measured in the absence and presence of antibodies raised against purified human CETP. PLTP activities were present in all four species with highest values in pig $(11.7 \pm 1.2 \mathrm{U} / \mathrm{ml})$ and human plasma $(9.2 \pm 1.6$ $\mathrm{U} / \mathrm{ml})$. Considerable lower activities were found in rabbit $(3.5 \pm 0.6 \mathrm{U} / \mathrm{ml})$ and rat plasma $(1.6 \pm 0.7$ $\mathrm{U} / \mathrm{ml}$ ). These activities were not affected significantly by antibody against human CETP. CETP activities could be measured in human $(0.23 \pm 0.05 \mathrm{U} / \mathrm{ml})$ and in rabbit plasma $(0.19 \pm 0.03 \mathrm{U} / \mathrm{ml})$. CETP activity in human plasma was inhibited over $97 \%$ by antibody against human CETP. Plasma was chromatographed on a Superose 6 gel filtration column. Average HDL particle sizes in the four species differed notably and decreased in the order: rat HDL $>$ rabbit HDL $>$ human HDL $>$ pig HDL. A separation of the two lipid transfer activities was evident after gel filtration chromatography. The peak of the PLTP activity coeluted with a fraction of HDL particles with the size of human $\mathrm{HDL}_{2}$ (particle weights $300-375 \mathrm{kDa}$ ). CETP activity in human and rabbit plasma coeluted largely with relatively small HDL particles (particle weights $140-180 \mathrm{kDa}$ ). These results show that CETP and PLTP activitics are located in different macromolecular complexes.

Key words: Lipid transfer; Exchange; Cholesterylesters; Cholesterol; Triglycerides; Phospholipids; Lipoproteins

* Present address: Dept. of Pediatrics, Univ. Hospital, P.O. Box 9600, 2300 RC Lciden, The Netherlands.

Correspondence to: Dr. Arie van Tol, Dept. of Biochemistry, Erasmus University Rotterdam, P.O. Box 1738, 3000 DR Rotterdam, The Netherlands.
Abbreviations: apo, apolipoprotein; CETP, cholesteryl ester transfer protein; HDL, high density lipoprotein; LDL, low density lipoprotein; PLTP, phospholipid transfer protein; SDS-PAGE, sodium dodecyl sulphate polyacrylamide gel electrophoresis; TC, total cholesterol; TG, triglycerides; VLDL, very low density lipoprotein. 


\section{Introduction}

Plasma lipid transfer proteins have an important influence on lipoprotein composition and lipid metabolism [1,2]. The activity of these proteins may be related to atherogenesis. At least two plasma lipid transfer proteins have been recognized [3-6]. Most knowledge exists about the cholesteryl ester transfer protein (CETP or LTP-I) which transfers cholesteryl esters, triglycerides, and phospholipids between lipoproteins. The gene for this protein has been cloned and sequenced and codes for a highly hydrophobic protein [7]. Apparent molecular weights of the protein on SDS gels of 64-74 $\mathrm{kDa}$ have been reported $[4,6,8,9]$. Studies with monoclonal antibodies suggest that this protein is responsible for all cholesteryl ester transfer activity in plasma [10].

Less is known about another plasma lipid transfer protein, the phospholipid transfer protein (PLTP or LTP-II), which enhances transfer of phospholipids between lipoproteins $[11,12]$ or between phospholipid vesicles and HDL $[13,14]$. Some studies on its purification have appeared, but different molecular weights of $41 \mathrm{kDa}$ [5] and $69 \mathrm{kDa}$ [12] are reported.

In whole plasma the lipid transfer proteins may be complexed with lipoproteins. CETP is associated with a small-sized HDL subfraction after gel filtration chromatography of fasting plasma [15-17]. Also, electrophoretic and immunological methods have shown that CETP is located in apo A-I-containing lipoproteins [1820]. Localization studies of PLTP are not available. However, ultracentrifugation experiments have shown that PLTP is found in a HDL fraction with very high density $(1.20-1.26 \mathrm{~g} / \mathrm{ml})$ [13].

There is a considerable variation in the activity of CETP between species [21]. The activity of PLTP in different species is not well documented. In this report we present the activities of both proteins in human, rabbit, pig, and rat plasma measured in the absence, and in the presence of antibodies directed to human CETP. Furthermore, cholesteryl ester and phospholipid transfer activity profiles after gel filtration of plasma are presented.

\section{Methods}

\section{Materials}

Egg phosphatidylcholine (type III E), butylated hydroxy toluene and 5,5-dithiobis(2-nitrobenzoic acid) were obtained from Sigma (St. Louis, MO, U.S.A.). Cholesteryl $\left[1-{ }^{14}\right.$ Cloleate (spec. act., $57 \mathrm{Ci} / \mathrm{mol}$ ) was from NEN Research Products, E.I. du Pont de Nemours and Co. (Inc.), U.S.A. L-3-Phosphatidyl [N-methyl- $\left.{ }^{3} \mathrm{H}\right]$ choline, 1,2-dipalmitoyl (spec. act., $76 \mathrm{Ci} / \mathrm{mmol}$ ) was from Amersham International plc (Amersham, U.K.). Intralipid (10\%) was purchased from Kabi Vitrum (Stockholm, Sweden). Heparin (thromboliquine, $5000 \mathrm{U} / \mathrm{ml}$ ) was from Organon Teknika (Boxtel, The Netherlands). Dextran sulphate, phenyl-Sepharose, CNBr-activated Sepharose, Sepharose CL-4B, Superose 6 prep-grade and Mono-Q HR 5/5 column were purchased from Pharmacia (Uppsala, Sweden). CM-cellulose 52 was from Whatman Ltd. (Maidstone, U.K.). Heparin-Sepharose was prepared by coupling heparin to CNBr-activated Sepharose according to the manufacturers instructions (Pharmacia), Fasted plasma from human volunteers (age $32 \pm 6$ year), from Wistar rats (weighing $320 \pm 20 \mathrm{~g}$ ), from New Zealand white rabbits (weighing $2.7 \pm 0.2 \mathrm{~kg}$ ), and from Yorkshire pigs (weighing $61 \pm 6 \mathrm{~kg}$ ) was used.

\section{Purification of human CETP}

CETP was partially purified from the $d>1.18$ $\mathrm{g} / \mathrm{ml}$ fraction of human plasma by the method described by Morton and Zilversmit [3], using phenyl-Sepharose and CM-cellulose chromatography. The resulting CETP fraction was dialysed against $10 \mathrm{mM}$ Tris- $\mathrm{HCl}$, containing $50 \mathrm{mM} \mathrm{NaCl}$ and $1 \mathrm{mM}$ EDTA (pH 7.4), and was chromatographed on a heparin-Sepharose column $(1.3 \times 29 \mathrm{~cm})$, equilibrated with the same buffer, in order to remove the phospholipid transfer protein, which binds to the column $[4,14]$, while most other protcins, including CETP, do not bind under these conditions. The unbound fraction was dialysed against $25 \mathrm{mM}$ Tris- $\mathrm{HCl}$, containing 1 mM EDTA ( $\mathrm{pH}$ 7.4) and was further purified by anion exchange chromatography. Up to $15 \mathrm{mg}$ 
protein was applied to a Mono-Q HR 5/5 column, equilibrated with $25 \mathrm{mM}$ Tris- $\mathrm{HCl}, 1 \mathrm{mM}$ EDTA (pH 7.4), and eluted with a gradient from 0 to $400 \mathrm{mM} \mathrm{NaCl}$ in the same buffer. The flow rate was $2 \mathrm{ml} / \mathrm{min}$. When applied to a freshly washed column, CETP activity elutes in a sharp peak at about $80 \mathrm{mM} \mathrm{NaCl}$, while the bulk of proteins elute at higher salt concentrations. The fraction containing CETP activity was concentrated by spindialysis using the Centricon $10 \mathrm{mi}-$ croconcentrator (Amicon, Danvers, MA, U.S.A.) to 5-10 $\mathrm{mg}$ protein per $\mathrm{ml}$ and further purified by binding of CETP to an artificial triglyceride/ phospholipid emulsion (Intralipid, cf. Ref. 6). Intralipid was purified before use. $3 \mathrm{ml}$ Intralipid solution, containing 5\% sucrose, was layered under $9 \mathrm{ml} 0.5 \mathrm{mM}$ EDTA ( $\mathrm{pH} \mathrm{7.4)} \mathrm{solution} \mathrm{in} \mathrm{a}$ SW40 tube, and centrifuged for $15 \mathrm{~min}$ at 28000 rpm and $0-5^{\circ} \mathrm{C}$. The lipid cake was sliced off and resuspended in about $1 \mathrm{ml} 0.5 \mathrm{mM}$ EDTA $(\mathrm{pH}$ 7.4) solution and immediately used for further experiments. The emulsion was incubated under $\mathrm{N}_{2}$ with concentrated Mono-Q fraction (45 mg triglycerides $/ \mathrm{mg}$ protein) in $150 \mathrm{mM} \mathrm{NaCl}$, containing $20 \mathrm{mM}$ Tris- $\mathrm{HCl}, 20 \mathrm{mM}$ dithiothreitol, $0.5 \mathrm{mM}$ EDTA (pH 7.4), for $15 \mathrm{~min}$ at $37^{\circ} \mathrm{C}$. After incubation, the mixture was put on ice and subsequently chromatographed on a Sepharose CL-4B column $(2.5 \times 40 \mathrm{~cm})$ equilibrated with 50 $\mathrm{mM} \mathrm{NH} \mathrm{NCO}_{3}$, containing $0.5 \mathrm{mM}$ EDTA $(\mathrm{pH}$ 8.0 ), at a flow of $50 \mathrm{ml} / \mathrm{h}$. Void volume fractions, containing the lipid emulsion and bound CETP activity, were lyophilized and delipidated by extraction with ethanol/ether $(\mathrm{v} / \mathrm{v}, 3: 2)$, as described by Hesler et al. [6]. The delipidated mate- rial was dissolved in $\mathrm{H}_{2} \mathrm{O}$ to a protein concentration of $0.1 \mathrm{mg} / \mathrm{ml}$ and assayed for CETP activity. SDS-PAGE in the presence of mercaptoethanol showed one band with a molecular weight of 66 $\mathrm{kDa}$ on staining with Coomassie brilliant blue. Table 1 shows a summary of the purification of human CETP.

\section{Preparation of antibody to CETP}

Antibodies were raised in a chicken. $50 \mu \mathrm{g}$ purified human CETP were injected intramuscularly into the thigh at two sites, followed by 2 booster injections of $50 \mu \mathrm{g}$ protein at 3-week intervals. A pre-immune-serum and antisera at several points of time were collected and tested for inhibition of CETP activity. IgG were isolated from the chickens eggs, according to the method of Jensenius et al. [22]. In short, egg yolks were diluted with $140 \mathrm{mM} \mathrm{NaCl}$, containing $10 \mathrm{mM}$ Tris- $\mathrm{HCl}, 0.1 \% \quad \mathrm{NaN}_{3}(\mathrm{pH} 7.4)$, and yolk lipid/ protein complexcs were precipitated with dextran sulphate $/ \mathrm{CaCl}_{2}$. The lipids were subsequently removed by centrifugation. The IgG present in the supernatant were then precipitated by addition of sodium-sulphate. The precipitate was dissolved and dialysed against buffered saline (see above) and stored at $4^{\circ} \mathrm{C}$.

Isolation of lipoproteins and radiolabelling of $L D L$ Isolation of $\mathrm{HDL}_{3}, \mathrm{HDL}, \mathrm{LDL}$, and VLDL was performed according to Havel et al. [23]. LDL was labelled with cholesteryl $\left[1-{ }^{14} \mathrm{C}\right]$ oleate by the method of Morton and Zilversmit [24]. Reisolation of LDL was done as described by Groener et al. [25].

TABLE 1

PURIFICATION OF HUMAN CETP

\begin{tabular}{lccccr}
\hline Fraction after & Protein (mg) & Activity (U) & $\begin{array}{l}\text { Specific activity } \\
(\mathrm{U} / \mathrm{mg})\end{array}$ & $\begin{array}{l}\text { Purification } \\
\text { factor }\end{array}$ & Recovery (\%) \\
\hline Plasma $d>1.18 \mathrm{~g} / \mathrm{III}$ & 22686 & 27.7 & 0.00122 & 1 & 100 \\
Phenyl-Sepharose & 596 & 20.4 & 0.0343 & 28 & 74 \\
CM-cellulose & 33.0 & 10.1 & 0.305 & 249 & 36 \\
Heparin-Sepharose & 29.1 & 9.22 & 0.317 & 259 & 33 \\
Mono Q & 2.5 & 5.59 & 2.24 & 1828 & 20 \\
$\quad$ Intralipid binding & & & & 19873 & 6 \\
$\quad$ (after delipidation) & 0.069 & 1.68 & 24.3 & & \\
\hline
\end{tabular}


Assay of cholesteryl ester transfer protein activity

Cholesteryl ester transfer protein (CETP) activity in plasma and column fractions was measured by exchange of radiolabelled cholesteryl oleate between exogenous LDL and HDL and was performed as described [25] with the following modifications: VLDL and LDL from plasma samples were precipitated with phosphotungstate $/ \mathrm{Mg}^{2+}$ [26] instead of polyethyleneglycol, and the supernatant was used as source for CETP. After $16 \mathrm{~h}$ the incubation was stopped by cooling on ice and subsequently LDL was precipitated with $300 \mu \mathrm{l} 0.1 \mathrm{M}$ sodium-phosphate $(\mathrm{pH}$ 7.4) and $167 \mu \mathrm{l}$ of a $0.1 \mathrm{M} \cdot \mathrm{MnCl}_{2}$ solution [15], followed by centrifugation $(30 \mathrm{~min}, 1500 \times \mathrm{g}$ ) to remove the precipitate. Radioactivity in HDL was measured by liquid scintillation counting. Activity is expressed in $\mathrm{U} / \mathrm{ml}$, i.e. $\mu \mathrm{mol}$ cholesteryl ester exchanged $/ \mathrm{h} / \mathrm{ml}$.

\section{Assay of phospholipid transfer protein activity}

Phospholipid transfer protein (PLTP) activity was measured in a phospholipid vesicles-HDL assay system. This assay is specific for PLTP activity, since CETP, which does promote exchange of phospholipids between lipoproteins, shows no significant activity in this system under the conditions used [5] (see also Results and Discussion). Radiolabelled vesicles were prepared by mixing $10 \mu$ moles egg phosphatidylcholine with $1 \mu \mathrm{Ci}$ of $\left[{ }^{3} \mathrm{H}\right]$ phosphatidylcholine and $0.1 \mu \mathrm{mol}$ butylated hydroxytoluene. The lipids were dried under $\mathrm{N}_{2}$ and $1 \mathrm{ml} 150 \mathrm{mM}$ $\mathrm{NaCl}$, containing $10 \mathrm{mM}$ Tris- $\mathrm{HCl}$ and $1 \mathrm{mM}$ EDTA ( $\mathrm{pH} 7.4$ ), was added. The lipids were dispersed by sonicating three times for $5 \mathrm{~min}$ on ice with a probe type sonifier. Measurement of facilitated transfer of phosphatidylcholine from vesicles to HDL was determined essentially by the method described by Damen et al. [14]. In short, plasma samples or column fractions were incubated with vesicles and HDL for $1.5 \mathrm{~h}$ at $37^{\circ} \mathrm{C}$. The reaction was stopped on ice and the vesicles were precipitated by adding $320 \mathrm{mM}$ $\mathrm{NaCl}, 92 \mathrm{mM} \mathrm{MnCl}_{2}$ and $200 \mathrm{U} / \mathrm{ml}$ heparin (final concentrations). The precipitate was removed by centrifugation and radioactivity was determined in the supernatant by liquid scintillation counting. Activity is expressed in $\mathrm{U} / \mathrm{ml} \mathrm{(1}$ unit is defined as $1 \mu$ mol phospholipid transferred $/ h$ ) and is corrected for spontaneous transfer at $37^{\circ} \mathrm{C}$. Sample amounts were chosen such that phospholipid transfer remained in the linear range with respect to incubation time and sample volume. The transfer of radioactive phospholipid during the $1.5 \mathrm{~h}$ incubation was less than $20 \%$ of total vesicle radioactivity.

\section{Gel filtration of fasting plasma}

Plasma from 2 subjects of each of the 4 species was chromatographed on a Superose 6 prep grade column (100 ml, Pharmacia) according to Van Gent and Van Tol [17]. $2 \mathrm{ml}$ plasma was used, the flow rate was $0.25 \mathrm{ml} / \mathrm{min}$, and $2.73-\mathrm{ml}$ fractions were collected. The elution buffer was $150 \mathrm{mM}$ $\mathrm{NaCl}$, containing $2 \mathrm{mM}$ sodium phosphate, $5 \mathrm{mM}$ EDTA and $0.02 \% \mathrm{NaN}_{3}$ (pH 7.4). Each fraction was tested for CETP activity, PLTP activity, total cholesterol and total triglycerides. Recoveries of CETP activity $(n=4)$, PLTP activity $(n=6)$, total cholesterol $(n=6)$, and triglycerides $(n=6)$ were $76 \pm 7 \%, 85 \pm 14 \%, 99 \pm 9 \%$ and $76 \pm 8 \%$, respectively.

\section{Other methods}

Total cholesterol and triglycerides were measured enzymatically using commercially available kits (Boehringer Mannheim, F.R.G., kit no. 310328 plus cholesterol esterase, and kit no. 877557 , resp.). Protein concentrations were determined by the method of Lowry et al. [27] or Sedmak and Grossberg [28] with bovine serum albumin as a standard. SDS-PAGE was performed according to Laemmli [29].

\section{Results}

\section{Lipid transfer activities in different species}

Total cholesterol, triglycerides, and the activities of two distinct lipid transfer proteins (CETP and PLTP) were measured in plasma of four different species: man, rabbit, pig, and rat. Table 2 shows a summary of the results of these measurements. Both human and rabbit plasma have relatively high CETP activity, while the activities in pig and rat plasma are undetectable. PLTP activity is present in all four species tested, although plasma activity levels differ markedly. The 
TABLE 2

CETP AND PLTP ACTIVITIES, TOTAL CHOLESTEROL, TRIGLYCERIDES, IN HUMAN, RABBIT, PIG, AND RAT PLASMA

\begin{tabular}{lllcl}
\hline & Human $(n=6)$ & Rabbit $(n=7)$ & Pig $(n=7)$ & Rat $(n=6)$ \\
\hline CETP & $0.225 \pm 0.046$ & $0.192 \pm 0.029$ & $0.002 \pm 0.002$ & $0.002 \pm 0.001$ \\
PLTP & $9.2 \pm 1.6$ & $3.5 \pm 0.6$ & $11.7 \pm 1.2$ & $1.6 \pm 0.7$ \\
TC & $4.89 \pm 0.95$ & $1.42 \pm 0.65$ & $1.95 \pm 0.33$ & $1.64 \pm 0.10$ \\
TG & $0.97 \pm 0.36$ & $0.42 \pm 0.10$ & $0.49 \pm 0.12$ & $0.74 \pm 0.11$ \\
\hline
\end{tabular}

CETP activity was measured in $10 \mu \mathrm{l}$ plasma and is expressed in $\mathrm{U} / \mathrm{ml}$. PLTP activity was measured in $5 \mu \mathrm{l}$ plasma samples, ten times diluted in $150 \mathrm{mM} \mathrm{NaCl}$, containing $10 \mathrm{mM}$ sodium phosphate, $1 \mathrm{mM}$ EDTA and $0.01 \% \mathrm{NaN}_{3}$ ( $\mathrm{pH} 7.4$ ), and is expressed in $\mathrm{U} / \mathrm{ml}$. Total cholesterol (TC) and triglycerides (TG) were determined enzymatically and are given in $\mathrm{mM}$.

activity of PLTP was highest in pig and human plasma, and much lower in rabbit and rat plasma.

\section{Inhibition studies with antibodies to CETP}

CETP was isolated from human plasma by several sequential purification steps. The final preparation showed one band on SDS-PAGE with an apparent molecular weight of 66000 and was used to immunize a chicken. Antibodies were detectable both in the serum and in the egg yolk of the chicken by immunoprecipitation and activity measurements. IgG isolated from the egg yolk were tested for the ability to inhibit CETP. In-

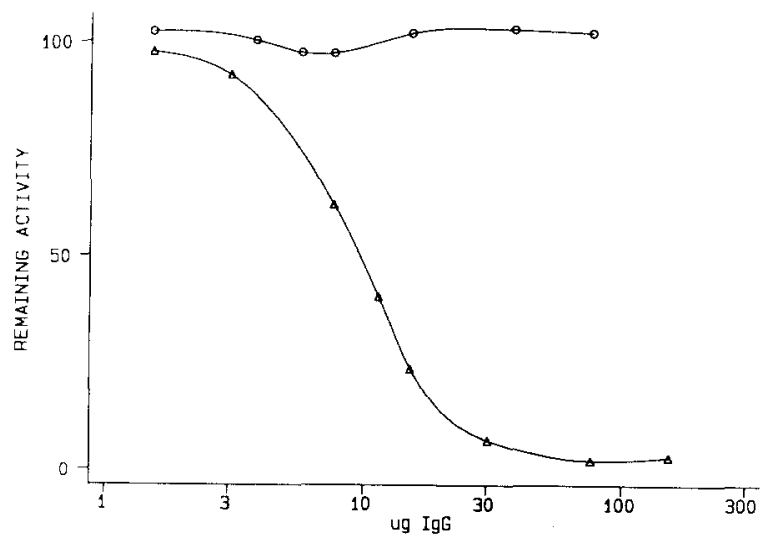

Fig. 1. Inhibition of CETP activity by anti-human CETP IgG. Samples $(15 \mu \mathrm{l})$ of a human serum pool were assayed for CETP activity in the presence of varying amounts of anti-human CETP egg IgG $(\Delta-\Delta)$, or non-immune egg IgG $(\mathrm{O}-O)$. CETP activity is expressed as percentage of control activity (no antibody). This is a representative experiment from a series of 2 , using two different IgG preparations. The effects of non-immune IgG are considered insignificant. creasing amounts of egg $\operatorname{IgG}$ were incubated with $15 \mu \mathrm{l}$ of a human serum pool and the remaining CE'IP activity was measured (Fig. 1). CETP was inhibited over $97 \%$ in the presence of $70 \mu \mathrm{g}$ anti-human CETP IgG. Subsequently, we assayed CETP and PLTP activity in human, rabbit and pig plasma and determined the effect of anti-human CETP IgG on these activities, using non-immune egg IgG as control. Part of the results are shown in Table 3. The CETP activities in the three human plasma samples were reduced by $97 \%$ or more when incubated with anti-human CETP IgG. PLTP activities in these plasmas were however unaffected by the antibodies. Rabbit CETP activity is inhibited by about $23 \%$ using the same conditions (not shown). Rabbit and pig plasma PLTP activities appeared to be unaffected by the presence of anti-human CETP IgG.

TABLE 3

INHIBITION OF CETP AND PLTP ACTIVITIES IN HUMAN PLASMA BY ANTI-HUMAN CETP IgG

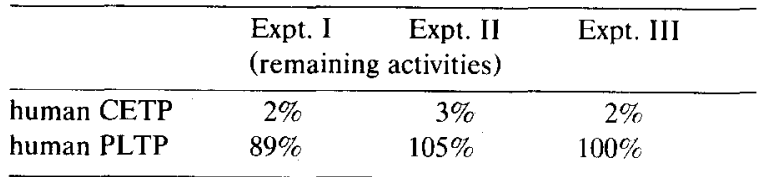

Activities are presented as \% of the original activity. CETP activity was measured in $15 \mu \mathrm{l}$ plasma in the presence of 76 $\mu \mathrm{g}$ anti-human CETP cgg IgG or non-immune egg IgG. PLTP activity in $5 \mu 1$ plasma samples, diluted 10 times in $150 \mathrm{mM}$ $\mathrm{NaCl}$, containing $10 \mathrm{mM}$ sodium phosphate, $1 \mathrm{mM}$ EDTA,

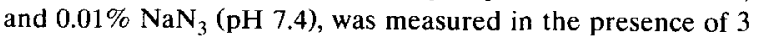
$\mu \mathrm{g}$ anti-human CETP egg IgG or non-immune egg IgG. 
Localisation of transfer protein activities as determined by gel filtration of plasma

In order to examine with which lipoprotein fraction CETP and PLTP are associated, plasma was fractionated by gel filtration chromatography. Plasma samples from two subjects of each of the four species were chromatographed as described in Methods. All fractions were tested for total cholesterol and triglyceride content as well as CETP and PLTP activities. The column profiles obtained in this way from one individual of each species are shown in Figs. 2 and 3. Both individual plasma samples gave essentially the same results. Upon measurement of the lipids in the column fractions, the elution profiles show three lipoprotein peaks (Figs. 2 and 3, A and C) with the exception of rat plasma, which shows only two (cf. Refs. [30-32]). The first peak, present in the void volume, contains VLDL, consistent with its relatively high triglyceride and low cholesterol content. The second peak corresponds with LDL and the third peak with HDL particles. By contrast, the second peak in rat plasma corresponds with HDL (with a small contribution of LDL and a substantial contribution of the large $\mathrm{HDL}_{1}$ ). LDL from human as well as rabbit plasma are mostly recovered in column fractions 10 and 11 . Therefore the LDL in human and rabbit plasma are of comparable size. Pig LDL tend to be slightly smaller than human LDL. HDL sizes of
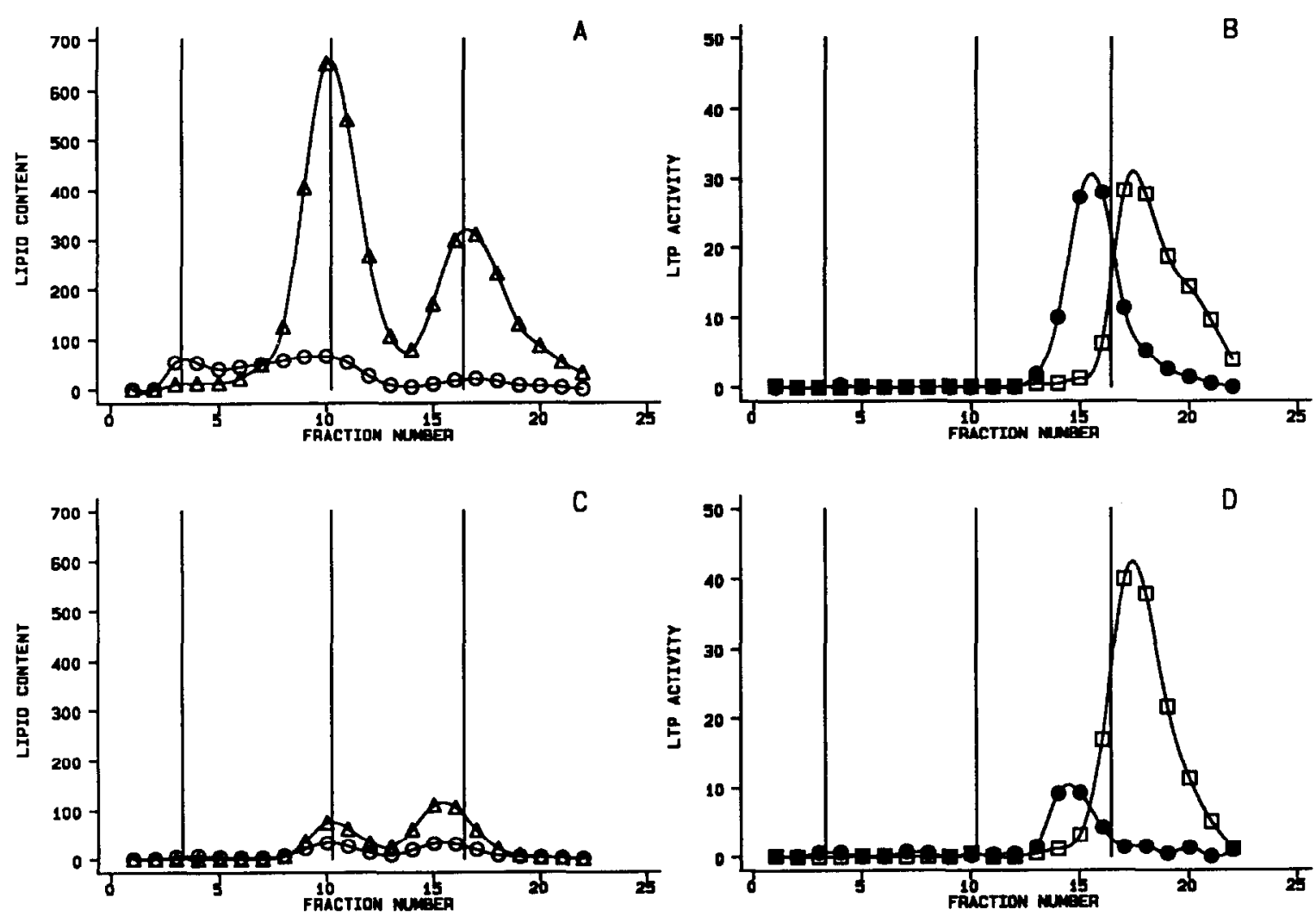

Fig. 2. Gelfiltration chromatography of human and rabbit plasma. Samples ( $2 \mathrm{ml})$ of human (A, B) and rabbit (C, D) plasma were chromatographed on a Superose 6 column. Column fractions were assayed for total cholesterol $(\Delta-\Delta)$ and triglyceride $(0-0)$ content. Lipid contents of the fractions are given in $\mathrm{nmol} / \mathrm{ml}$ of injected plasma (summation of all fractions results in total plasma concentration in nmoles $/ \mathrm{ml}$ ). Aliquots of $100 \mu \mathrm{l}$ and $5 \mu \mathrm{l}$ were taken and assayed for CETP ( $\square-\square)$ and PLTP $(\bullet)$ activity, respectively. Activities in the fractions are expressed in $\mathrm{nmol} / \mathrm{ml}$ injected $\mathrm{plasma} / \mathrm{h}(\mathrm{CETP})$ or $\mathrm{nmol} / \mathrm{ml}$ injected plasma/min (PLTP). The three vertical lines from left to right represent the peak elution volumes of isolated human VLDL, LDL and HDL, respectively. The column was further calibrated as described in [17]. 

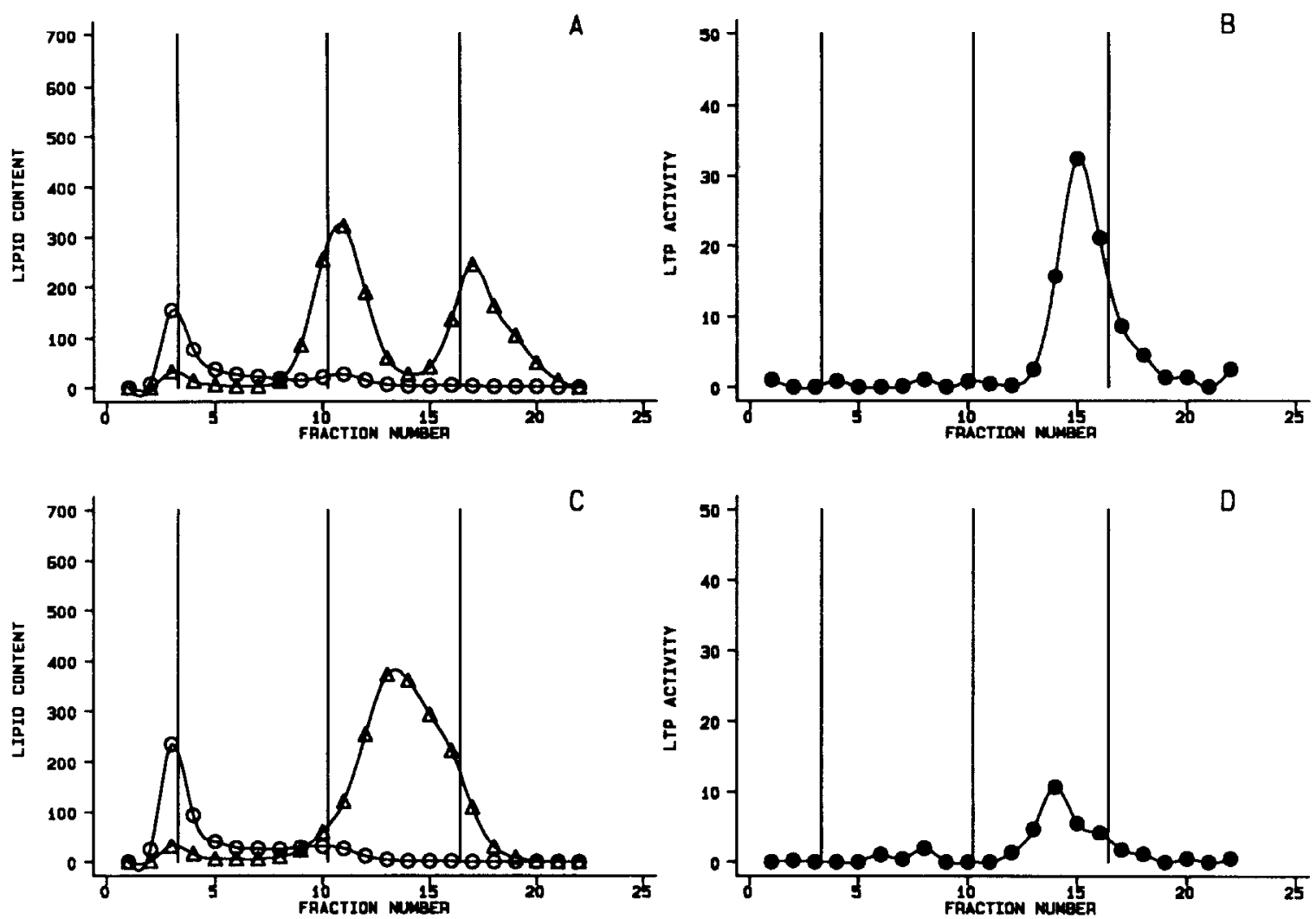

Fig. 3. Gel filtration chromatography of pig (A, B) and rat (C, D) plasma. For further details see the legend to Fig 2.

the different mammals are clearly different. As mentioned above, rat HDL have the biggest average size, due to the large amounts of big, apo E-rich HDL in plasma from this species. The average size of HDL from rabbit plasma is also bigger than human HDL, while HDL from pig plasma, just like pig LDL, are smaller than the human counterpart.

From the lipid transfer activity patterns (Figs. 2 and 3, B and D) it is apparent that CETP activity in human and rabbit plasma coelutes with a subfraction of relatively small HDL particles and may elute to some extent as free protein molecules. The CETP activity peak elutes at an apparent molecular weight of about $160 \mathrm{kDa}$. PLTP activity also coelutes with HDL, but mainly with a subfraction of a relatively large size. In human and pig plasma highest activity elutes at an apparent molecular weight of about $300 \mathrm{kDa}$, while in rat and rabbit plasma a larger apparent molecular weight of about $375 \mathrm{kDa}$ is observed.
Taken together, it is clear that PLTP and CETP activitics clute in different fractions.

\section{Discussion}

The existence of two separate plasma lipid transfer proteins (CETP and PLTP) has been described [4,5]. Apart from its activity in human plasma, PLTP activity has also been reported for rat plasma $[11,33]$. In the present study we have shown that, in addition to human and rat plasma, plasma from rabbits and pigs also contains PLTP activity, although the activities differ markedly between species.

The CETP activities in human and rabbit plasma were found to be of the same order of magnitude. This was surprising as literature [21] indicates a higher level in the rabbit. However it was also shown that rabbit plasma CETP activity is very sensitive to dietary conditions [34]. Also the use of rabbits with different genetic back- 
grounds could be responsible for the apparent discrepancy. In our study, in accordance with published data [21], we could not detect appreciable CETP activity in pig and rat plasma. Whether this is a consequence of low rates of synthesis and secretion of CETP protein, or the result of the presence of an inhibitor protein in plasma, is not yet clear. Nagashima et al. [35] reported significant amounts of CETP mRNA in human, rhesus, and rabbit liver, but very low or undetectable levels in pig, rat, and mouse liver. However, other investigators have reported that muscle, heart and adipose tissue of rats and mice also contain CETP-like mRNA species [36]. The presence of an inhibitor protein in human, pig, and rat plasma could mask the activity of CETP in pig and rat plasma $[37,38]$.

Experiments with a polyclonal antibody preparation against human CETP show that CETP activity in a human plasma sample is almost completely inhibited. Using the same antibodies, CETP activity in rabbit plasma is inhibited by about $23 \%$ under the conditions used. This is probably caused by crossreactivity between rabbit CETP and the anti-human CETP IgG. Some crossreactivity is not surprising since the amino acid sequence of rabbit CETP, obtained from a cDNA sequence, shows $81 \%$ homology with human CETP [35].

Facilitated phospholipid transfer between phospholipid vesicles and HDL, by any of the plasma samples tested, is not inhibited significantly by anti-human CETP IgG. It can be concluded that phospholipid transfer activity in human plasma measured with this assay mainly results from the activity of PLTP.

The gel filtration experiments also show that the two lipid transfer activities are mediated by different proteins. In both human and rabbit plasma, PLTP activity is separated from CETP transfer activity. CETP coelutes with the trailing edge of the HDL peak, suggesting its association with small HDL particles. In all experiments performed the complex has a particle weight between 140 and $180 \mathrm{kDa}$. In contrast, PLTP elutes in the front of the HDL peak, suggesting a complex of relatively large size with particle weights ranging from about $300 \mathrm{kDa}$ in human and pig plasma to about $375 \mathrm{kDa}$ in rat and rabbit plasma.
This apparently is in contrast to results of ultracentrifugation experiments, where PLTP was found in the smaller, denser HDL subclasses, together with CETP [13]. However, results obtained by ultracentrifugation may not represent the situation in whole plasma, since, after prolonged ultracentrifugation, both proteins are recovered in the lipoprotein free fraction due to dissociation from the lipoprotein particles $[13,15]$.

The average HDL sizes in the various species differ markedly. It was published recently that the size of HDL is increased in patients with CETP deficiency [39]. This big HDL is also enriched in apo $E$ and resembles HDL from rat, a species with very low plasma CETP activity. The authors hypothesized that HDL size may be strongly related to plasma CETP activity levels. From our present data it is clear, however, that the situation is more complicated. The results obtained in pig plasma, with relatively small HDL in combination with virtually zero CETP activity, show that CETP activity may not be the most important factor determining HDL size. We recently described a new lipid transfer reaction in human plasma, resulting in net mass transfer of cholesteryl ester from LDL to HDL [40]. This reaction contributes to an increase in the size of HDL, opposing the known effects of CETP.

\section{Acknowledgements}

This study was supported by grant no. 87.060 from the Netherlands Heart Foundation. The research of J.E.M.G. was made possible by a fellowship from the Royal Academy of Arts and Science. The expert assistence of $\mathrm{T}$. van Gent and L. Scheek is gratefully acknowledged. We would like to thank Dr. H. Blankert and F. Rietveld from the Department of Animal Husbandry, Wageningen Agricultural University, for performing the immunizations.

\section{References}

1 Tall, A.R, Plasma lipid transfer proteins, J. Lipid Res., 27 (1986) 361

2 Morton, R.E., Interaction of lipid transfer protein with plasma lipoproteins and cell membranes, Experientia, 46 (1990) 552. 
3 Morton, R.E. and Zilversmit, D.B., Purification and characterization of lipid transfer protein(s) from human lipoprotein-deficient plasma, J. Lipid Res., 23 (1982) 1058.

4 Albers, J.J., Tollefson, J.H., Chen, C.-H. and Steinmetz, A., Isolation and characterization of human plasma lipid transfer proteins, Arteriosclerosis, 4 (1984) 49.

5 Tall, A.R., Abreu, E. and Shuman, J., Separation of a plasma phospholipid transfer protein from cholesteryl ester/phospholipid exchange protein, J. Biol. Chem., 258 (1983) 2174.

6 Hesler, C.B., Swenson, T.L. and Tall, A.R., Purification and characterization of a human plasma cholesteryl ester transfer protein, J. Biol. Chem., 262 (1987) 2275.

7 Drayna, D., Jarnagin, A.S., McLean, J., Henzel, W., Kohr, W., Fielding, C. and Lawn, R., Cloning and sequencing of human cholesteryl ester transfer protein cDNA, Nature, 327 (1987) 632.

8 Jarnagin, A.S., Kohr, W. and Fielding, C., Isolation and specificity of a $M_{\mathrm{T}} 74,000$ cholesteryl ester transfer protein from human plasma, Proc. Natl. Acad. Sci. U.S.A., 84 (1987) 1854.

9 Kato, H., Nakanishi, T., Arai, H., Nishida, H.I. and Nishida, T., Purification, microheterogeneity, and stability of human lipid transfer protein, J. Biol. Chem., 264 (1989) 4082.

10 Hesler, C.B., Tall, A.R., Swenson, T.L., Weech, P.K., Marcel, Y.L. and Milne, R.W., Monoclonal antibodies to the $M_{r} 74,000$ cholesteryl ester transfer protein meutralize all of the cholesteryl ester transfer activities in human plasma, J. Biol. Chem., 263 (1987) 5020.

11 Eisenberg, S., Effect of temperature and plasma on the exchange of apolipoproteins and phospholipids between rat plasma-very low density lipoproteins, J. Lipid Res., 19 (1978) 229.

12 Tollefson, J.H., Ravnik, S. and Albers, J.J., Isolation and characterization of a phospholipid transfer protein (LTP II) from human plasma, J. Lipid Res., 29 (1988) 1593.

13 Tall, A.R., Forester, L.R. and Bongiovanni, G.L., Facilitation of phosphatidylcholine transfer into high density lipoproteins by an apolipoprotein in the density $1.20-1.26$ $\mathrm{g} / \mathrm{ml}$ fraction of plasma, J. Lipid Res., 24 (1983) 277.

14 Damen, J., Regts, J. and Scherphof, G., Transfer of $\left[{ }^{14} \mathrm{C}\right]$ phosphatidylcholine between liposomes and human plasma high density lipoprotein. Partial purification of a transferstimulating plasma factor using a rapid transfer assay, Biochim. Biophys. Acta, 712 (1982) 444.

15 Pattnaik, N.M. and Zilversmit, D.B., Interaction of cholesteryl ester exchange protein with human plasma lipoproteins and phospholipid vesicles, J. Biol. Chem., 254 (1979) 2782.

16 Tall, A., Sammett, D. and Granot, E., Mechanisms of enhanced cholesteryl ester transfer from high density lipoproteins to apolipoprotein B-containing lipoproteins during alimentary lipemia, J. Clin. Invest., 77 (1986) 1163.

17 Van Gent, T. and Van Tol, A., Automated gel permeation chromatography of plasma lipoproteins by preparative fast protein liquid chromatography, J. Chromatogr., 525 (1990) 433.
18 Cheung, M.C., Wolf, A.C., Lum, K.D., Tollefson, J.H. and Albers, J.J., Distribution and localisation of lecithin:cholesterol acyl transferase and cholesteryl ester transfer activity in A-I-containing lipoproteins, J. Lipid Res., 27 (1986) 1135.

19 Francone, O.L., Gurakar, A. and Fielding, C., Distribution and functions of lecithin:cholesterol acyl transferase and cholesteryl ester transfer protein in plasma lipoproteins, $\mathrm{J}$. Biol. Chem., 264 (1989) 7066.

20 Marcel, Y.L., McPherson, R., Hogue, M., Czamecka, H., Zawadzki, Z., Weech, P.K., Whitlock, M.E., Tall, A.R. and Milne, R.W., Distribution and concentration of cholesteryl ester transfer protein in plasma of normolipidemic subjects, J. Clin. Invest., 85 (1990) 10.

$21 \mathrm{Ha}$, Y.C. and Barter, P.J., Differences in plasma cholesteryl ester transfer activity in sixteen vertebrate species, Comp. Biochem. Physiol., 71B (1982) 265.

22 Jensenius, J.C., Andersen, I., Hau, J., Crone, M. and Koch, C., Eggs: conveniently packaged antibodies. Methods for purification of yolk IgG, J. Immunol. Meth., 46 (1981) 63.

23 Havel, R.J., Eder, H.A. and Bragdon, J.H., The distribution and chemical composition of ultracentrifugally separated lipoproteins in human serum, J. Clin. Invest., 34 (1955) 1345

24 Morton, R.E. and Zilversmit, D.B., A plasma inhibitor of triglyceride and cholesteryl ester transfer activities, J. Biol. Cheml., 256 (1981) 11992.

25 Groener, J.E.M., Pelton, R.W. and Kostner, G.M., Improved estimation of cholesteryl ester transfer/exchange activity in serum or plasma, Clin Chem., 32 (1986) 283.

26 Lopes-Virella, M.F., Stone, P., Ellis, S. and Colwell, J A., Cholesterol determination in high-density lipoproteins separated by three different methods, Clin. Chem., 23 (1977) 882 .

27 Lowry, O.II., Rosebrough, N.J., Farr, A.L. and Randall, R.J., Protein measurement with the Folin phenol reagent, J. Biol. Chem., 193 (1951) 265.

28 Sedmak, J.J. and Grossberg, S.E., A rapid, sensitive, and versatile assay for protein using coomassie brilliant blue G250, Anal. Biochem., 79 (1977) 544.

29 Laemmli, U.K., Cleavage of structural proteins during the assembly of the head of bacteriophage T4, Nature, 227 (1970) 680 .

30 Dallinga-Thie, G.M., Groot, P.H.E. and Van Tol, A., The distribution of apolipoprotein A-IV among lipoprotein subclasses in rat serum, J. Lipid Res., 26 (1985) 970.

$31 \mathrm{Ha}$, Y.C. and Barter, P.J., Rapid separation of plasma lipoproteins by gel permeation chromatography on agarose gel Superose 6B, J. Chromatogr., 341 (1985) 154.

32 Groener, J.E.M., van Gent, T. and van Tol, A., Effect of lipid transfer protein on plasma lipids, apolipoproteins and metabolism of high-density lipoprotein cholesteryl ester in the rat, Biochim. Biophys. Acta, 1002 (1989) 93.

$33 \mathrm{Ihm}$, J., Ellsworth, J.L., Chataing, B. and Harmony, J.A.K., Plasma protein-facilitated coupled exchange of phosphatidylcholine and cholesteryl ester in the absence of cholesterol esterification. J. Biol. Chem., 257 (1982) 4818. 
34 Quig, D.W. and Zilversmit, D.B., Plasma lipid transfer activity in rabbits: effect of dietary hyperlipidemias, Atherosclerosis, 70 (1988) 263.

35 Nagashima, M., McLean, J.W. and Lawn, R.M., Cloning and mRNA tissue distribution of rabbit cholesteryl ester transfer protein, J. Lipid Res., 29 (1988) 1643.

36 Cheng Jiang, X., Moulin, P., Quinet, E., Goldberg, I.J., Yacoub, L.K., Agellon, L.B., Compton, D., SchnitzerPolokoff, R. and Tall, A.R., Mammalian adipose tissue and muscle are major sources of lipid transfer protein mRNA, J. Biol. Chem. 266 (1991) 4631.

37 Son, Y.-S.C. and Zilversmit, D.B., Purification and characterization of human plasma proteins that inhibit lipid transfer activities, Biochim. Biophys. Acta, 795 (1984) 473.
38 Nishide, T., Tollefson, J.H. and Albers, J.J., Inhibition of lipid transfer by a unique high density lipoprotein subclass containing an inhibitor protein, J. Lipid Res., 30 (1989) 149.

39 Yamashita, S., Sprecher, D.L., Sakai, N., Matsuzawa, Y., Tarui, S. and Hui, D.Y., Accumulation of apolipoprotein E-rich high density lipoproteins in hyperalphalipoproteinemic human subjects with plasma cholesteryl ester transfer protein deficiency, J. Clin. Invest., 86 (1990) 688.

40 Van Tol, A., Scheek, L.M. and Groener, J.E.M., Net mass transfer of cholesterylesters from low density lipoproteins to high density lipoproteins in plasma from normolipidemic subjects, Arterioscler. Thromb., 11 (1991) 55. 